\title{
Productivity and Profitability of Pearl Millet as Affected by Zinc and Iron Application in Arid and Semi-arid Region
}

\author{
Moola Ram ${ }^{1 *}$, R.C. Meena ${ }^{2}$, H.P. Parewa ${ }^{3}$ and Durgashankar Meena ${ }^{1}$ \\ ${ }^{1}$ Agricultural Research Station, Mandor, Jodhpur, Rajasthan, India \\ ${ }^{2}$ AICRP-Pearl Millet, Agriculture University Jodhpur, Mandor, Rajasthan, India \\ ${ }^{3}$ College of Agriculture, Sumerpur, Pali, Rajasthan, India \\ *Corresponding author: meenarc2004@yahoo.co.in (ORCID ID: 0000-0001-9640-6563)
}

Paper No. 922

Received: 18-06-2021

Revised: 20-08-2021

Accepted: 15-09-2021

\begin{abstract}
The field experiment was conducted in Randomized Block Design (RBD) with three replications at Agricultural Research Station (ARS), Mandor, during the rainy season of 2018 on sandy loam soil of low nitrogen, low phosphorus, low zinc, low iron and medium potassium content with $7.8 \mathrm{pH}$. The soil application of zinc sulphate heptahydrate @ $25 \mathrm{~kg} / \mathrm{ha}$ at the time of sowing + foliar application of $0.5 \%$ solution of ferrous sulphate at 30 and 45 days after sowing recorded 9\%, 40.7\%, 9.5\% and 6.9\% higher plant height, number of tillers/plant, panicle length and panicle girth at harvest, respectively over control. The grain yield (38.9 q/ha) with soil application of zinc sulphate @ $25 \mathrm{~kg} / \mathrm{ha}+$ foliar application of $0.5 \%$ ferrous sulphate solution was increased by $47 \%$ over micronutrient deficient control. This treatment also recorded a maximum net return (₹ 57632/ha) with a B: C ratio of 4.15 .

\section{HIGHLIGHTS}

(0 The role of micronutrients (zinc and iron) is vital for various plant growth and developmental processes.

(0 Foliar application is readily available for plant uptake, and thus it becomes generally more effective than its soil application.

( Pearl millet growth parameters and yield can be increased substantially due to soil application of zinc sulphate and foliar application of ferrous sulphate in western Rajasthan conditions.
\end{abstract}

Keywords: Pearl millet, productivity, zinc sulphate, ferrous sulphate, soil \& foliar application

Pearl millet is popularly known as "Bajra" and belongs to the family of Gramineae. Pearl millet is a coarse grain crop suitable to cultivate in drylands and considered the poor man's source of staple nourishment. It is grown in many countries, China, India, South-Eastern Asia, Sudan, Pakistan, Arabia, Russia, \& Nigeria. It is produced in the arid and semi-arid regions with fourth place after rice, wheat and sorghum, both in the area (7.41 mha) and production $(10.30 \mathrm{mt})$ with a yield of $1391 \mathrm{~kg} / \mathrm{ha}$ (Satyavathi 2021). Significant pearl millet producing states in India are Rajasthan, Maharashtra, Haryana, Uttar Pradesh and Gujarat; however, its productivity is high in Tamil Nadu. Pearl millet is used for both human food as well as valuable animal fodder. Its grains have very high nutritional value and are traditionally used for human consumption and fodder is used for livestock, both in fresh and dried forms. Although Rajasthan contributes about 50\% of the total pearl millet area in India, the average productivity in the State is low. Besides aberrant weather conditions, the soils of Rajasthan are poor in macro and micronutrients especially nitrogen,

How to cite this article: Ram, M., Meena, R.C., Parewa, H.P. and Meena, D. 2021. Productivity and Profitability of Pearl Millet as Affected by Zinc and Iron Application in Arid and Semi-arid Region. IJAEB, 14(03): 375-380.

Source of Support: None; Conflict of Interest: None 
phosphorus, sulphur, zinc and iron. There are multi-nutrient deficiencies in plants under such conditions, resulting in low yields (Sahu et al. 2007). There are $48 \%$ and $12 \%$ soils are deficient in $\mathrm{Zn}$ and $\mathrm{Fe}$, respectively, in India (Singh 2008). The role of micronutrients (zinc and iron) is vital for various plant growth and developmental processes (Bybordi and Mamedov 2010; Kim and Rees 1992; Rakshit et al. 2018). Many workers (Rahman et al. 2015; Singh et al. 2013; Kumawat et al. 2006; Salam et al. 2004) reported that growth attributes and productivity of crops were increased with the application of micronutrients ( $\mathrm{Zn}$ and $\mathrm{Fe}$ ). Given this, to enhance the productivity of pearl millet through zinc and iron application, an attempt was made in arid and semi-arid conditions of western Rajasthan.

\section{MATERIALS AND METHODS}

The field experiment was conducted during the Kharif (rainy) season of 2018 at Agricultural Research Station (ARS)-Mandor, Agriculture University, Jodhpur on sandy loam soil of low N, low $\mathrm{P}_{2} \mathrm{O}_{5}$, low $\mathrm{Zn}$ and low $\mathrm{Fe}$ and medium $\mathrm{K}_{2} \mathrm{O}$ content with $7.8 \mathrm{pH}$. There was 31.6 to $39.7^{\circ} \mathrm{C}$ mean daily maximum and 23.9 to $29.5{ }^{\circ} \mathrm{C}$ mean daily minimum temperature during the crop growing season. During the crop growth period (Standard Meteorological Week, $26^{\text {th }}$ to $38^{\text {th }}, 2018$ ), there were 15 rainy days and a total of $227.2 \mathrm{~mm}$ of rainfall was received. The Randomized Block Design (RBD) was used for experimenting with nine treatments and three replications. The treatments comprised of $\mathrm{T}_{1}$ RDF (except $\mathrm{Zn}$ and Fe fertilizers), $\mathrm{T}_{2}-\mathrm{T}_{1}+25 \mathrm{~kg} / \mathrm{ha}$ Zinc Sulphate (21\% zinc) as soil application at the time of sowing, $\mathrm{T}_{3}-\mathrm{T}_{1}+25 \mathrm{~kg} / \mathrm{ha}$ Ferrous Sulphate (19\% iron) as soil application at the time of sowing, $\mathrm{T}_{4}-\mathrm{T}_{1}+$ Foliar spray of $0.5 \%$ Zinc Sulphate $(21 \%$ zinc) solution at 30 and 45 days after sowing, $\mathrm{T}_{5}-\mathrm{T}_{1}$ + Foliar spray of $0.5 \%$ Ferrous Sulphate (19\% iron) solution at 30 and 45 days after sowing, $\mathrm{T}_{6}-\mathrm{T}_{1}+25$ $\mathrm{kg} / \mathrm{ha}$ Zinc Sulphate (21\% zinc) as soil application at the time of sowing + Foliar spray of $0.5 \%$ Zinc Sulphate (21\% zinc) solution at 35 days after sowing, $\mathrm{T}_{7}-\mathrm{T}_{1}+25 \mathrm{~kg} /$ ha Ferrous Sulphate (19\% iron) as soil application at the time of sowing + Foliar spray of $0.5 \%$ Ferrous Sulphate (19\% iron) solution at 35 days after sowing, $\mathrm{T}_{8}-\mathrm{T}_{1}+25 \mathrm{~kg} / \mathrm{ha}$ Zinc Sulphate (21\% zinc) as soil application at the time of sowing + Foliar spray of 0.5\% Ferrous Sulphate (19\% iron) solution at 30 and 45 days after sowing and $\mathrm{T}_{9}-\mathrm{T}_{1}$ $+25 \mathrm{~kg} / \mathrm{ha}$ Ferrous Sulphate (19\% iron) as soil application at the time of sowing + Foliar spray of $0.5 \%$ Zinc Sulphate (21\% zinc) solution at 30 and 45 days after sowing. Nitrogen and Phosphorus (30 kg each) were applied through urea and diammonium phosphate, respectively, at the time of sowing. The micronutrients ( $\mathrm{Zn}$ and $\mathrm{Fe}$ ) were applied through zinc sulphate heptahydrate $(21 \% \mathrm{Zn})$ and ferrous sulphate heptahydrate $(19 \% \mathrm{Fe})$, respectively, as per treatments at the time of sowing. The weeding was done at 30 days after sowing and then foliar applications of zinc and iron were done in respective plots as per treatments. A quantity of $5 \mathrm{~g}$ of zinc sulphate and ferrous sulphate was used per liter of water for making $0.5 \%$ solution. The solution was neutralised by mixing slaked lime@ $2.5 \mathrm{~g} /$ liter of water. Crop variety MPMH 17 was sown on $5^{\text {th }}$ July 2018. There was a gap in rainfall at 25 days after sowing therefore, one irrigation was applied at 25 DAS for proper growth and development of the crop. The observations of growth, yield and yield attributes were recorded at harvest.

\section{RESULTS AND DISCUSSION}

\section{Productivity}

Pearl millet growth and yield in terms of plant height, the number of tillers/plant, panicle length, panicle girth, grain yield, and fodder yield were significantly increased over control with soil application of zinc sulphate + foliar application of ferrous sulphate (Graph 1). The application of zinc sulphate@ $25 \mathrm{~kg} / \mathrm{ha}\left(\mathrm{T}_{2}\right)$ increased the plant height and number of tillers per plant by $7.6 \%$ and $3.3 \%$, respectively, over control. The vigorous growth of plants is attributed to cellular growth, differentiation and metabolism in which zinc plays a pivotal role leading to increased growth parameters (Prasad et al. 2014 in pearl millet, Sharma et al. 2004 in cluster bean; Khorgami and Farnia 2006 in chickpea). The effect of zinc, which is involved in IAA synthesis and also metabolic process in plants (Verma and Yadav 2004), resulted in increased plant height and number of tillers. Similar results of the significant effect of soil application of zinc sulphate on plant growth parameters were also reported by Karwasra and Kumar (2007), Sharma and Abrol (2007), Kharol et al. (2014) and Solanki et al. (2017). 


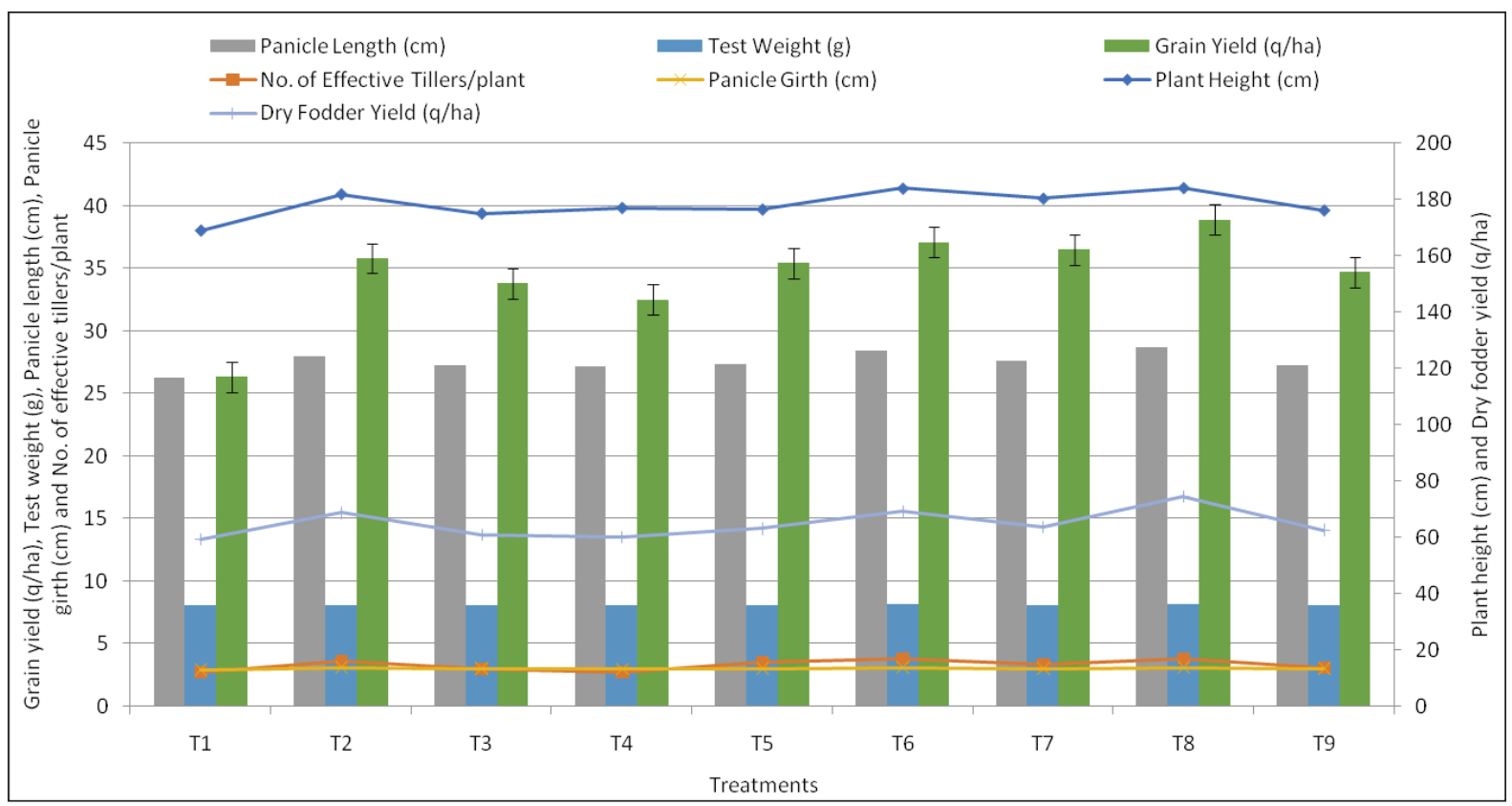

Graph 1: Growth and yield of pearl millet under different treatments of zinc and iron application

The growth and yield parameters substantially increased when soil application of zinc sulphate was supplemented with foliar application of ferrous sulphate $\left(\mathrm{T}_{8}\right)$. The plant height, the number of tillers/plant, panicle length and panicle girth was increased by $9 \%, 40.7 \%, 9.5 \%$ and $6.9 \%$, respectively over control. This might be due to the requirement of both the micronutrients by uptake through the soil and a foliar application. This may also be due to more response of supplemented foliar spray than soil application which is affected by different factors like soil $\mathrm{pH}$ and light-textured calcareous soil. The effect of foliar fertilization of iron on plant growth parameters was well documented by many workers (Trivedi et al. 2011 in soybean, Choudhary et al. 2018 in mungbean, Fouda and Elhamied, 2017 in cowpea, Bhamare et al. 2018 in french bean). The increased leaf area (Kumawat et al. 2006 and Ali et al. 2008) and increased stem diameter (Malakouti and Tehrani, 2005) also contributed to an increase in growth parameters due to foliar application of ferrous sulphate. The favourable effect of zinc and iron on photosynthetic and enzymatic activities would increase the vegetative growth of plants (Thalooth et al. 2006). The more carbohydrates synthesis due to ferrous supply may also be the reason for more growth of plants as reported by Sharma (2006) in fenugreek and (Kumawat et al. 2006) in mungbean. The maximum increase in the yield parameters and grain and fodder yield of pearl millet were recorded when soil application of zinc sulphate@ $25 \mathrm{~kg} /$ ha was supplemented with $0.5 \%$ foliar spray of ferrous sulphate. Foliar iron is readily available for plant uptake, and thus it becomes generally more effective than soil application. These results are also in confirmation to that of earlier reported by Vaja et al. (2020), Meena et al. (2018) in pearl millet, Gaffar et al. (2011) in Sugarcane, Habib (2012) in wheat, Roy et al. (2013), Jamal et al. (2018) in mungbean, Khan et al. (2017) and Elayaraja (2018) in sesame. The supplementary foliar spray might fulfil the nutritional demand of plants during pre-flowering stages leading to more photosynthetic efficiency with better partitioning of photosynthates from leaf to seed which increases seed weight (Bybordi and Malakouti 2003) and finally increase seed and stover yield (Guruprasad et al. 2009; Mondal et al. 2011; Saini and Singh 2017). A similar effect of foliar spray of iron was observed by Anitha et al. (2005) in oxisols.

\section{Profitability}

Net return: The maximum increase in net return was recorded (Graph 2) when soil application of zinc sulphate@ $25 \mathrm{~kg} /$ ha was supplemented with $0.5 \%$ foliar spray of ferrous sulphate $\left(\mathrm{T}_{8}\right)$ which was marginally followed by $\mathrm{T}_{6}(25 \mathrm{~kg} / \mathrm{ha}$ Zinc Sulphate ( $21 \%$ zinc) as soil application $+0.5 \%$ solution of Zinc Sulphate $(21 \%$ zinc) as foliar spray at 35 days after 


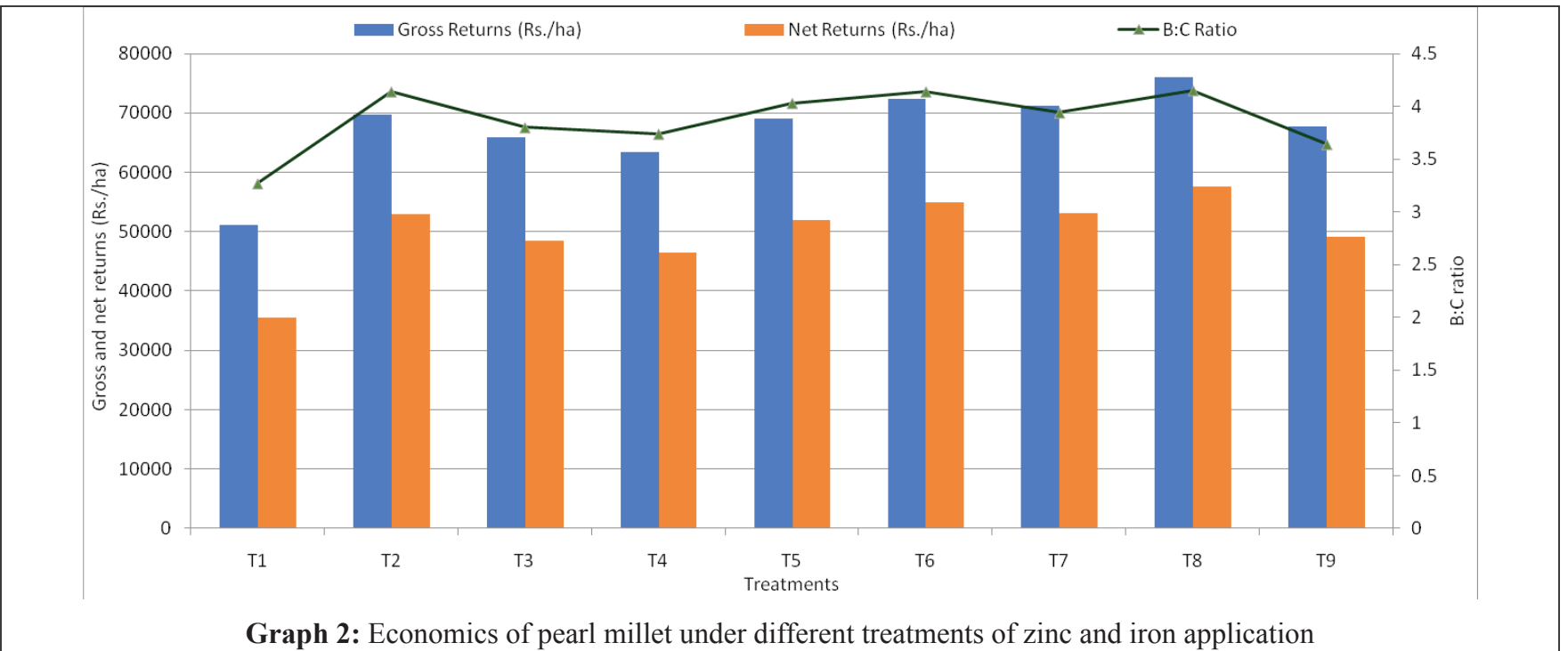

Graph 2: Economics of pearl millet under different treatments of zinc and iron application

sowing). Foliar iron is readily available for plant uptake and thus it becomes generally more effective than its soil application. The supplementary foliar spray increased the gross return which ultimately led to maximum net return. However, only soil application of zinc sulphate $\left(\mathrm{T}_{2}\right)$ increased the gross return with considerable no change in cost resulting in at par return with those supplemented with the foliar application which resulted in $48 \%$ higher net return over control. Similar findings of higher net returns were also reported by Sammauria and Yadav (2010) in fenugreek, Patel et al. (2011) in cowpea and Gupta (2012) in fennel.

$B: C$ ratio: The practicability and usefulness of treatments are ultimately judged in the B: C ratio, which is the deciding parameter for declaring the most suitable treatment combination. In the present experimentation, the B: C was maximum (4.15) in soil application of zinc sulphate @ $25 \mathrm{~kg} / \mathrm{ha}+$ foliar application of ferrous sulphate at 30 and 45 days after sowing $\left(\mathrm{T}_{8}\right)$. The control recorded minimum benefit-cost ratio (3.27) followed by 3.64 in $\mathrm{T}_{9}$ (soil application of $25 \mathrm{~kg} /$ ha Ferrous Sulphate (19\% iron) at the time of sowing + Foliar spray of $0.5 \%$ Zinc Sulphate ( $21 \%$ zinc) solution at 30 and 45 days after sowing). The higher cost of ferrous sulphate might reduce $B$ : $C$ ratio in ferrous sulphate soil application treatment. On the other hand, the comparatively lesser cost of zinc sulphate with better response in respect to yield might have resulted in a higher B: $C$ ratio in zinc sulphate treatment.

\section{CONCLUSION}

The majority of soils in India are significantly deficient in zinc and iron micronutrients. Rajasthan state is also not untouched in these deficiencies mainly because of edaphic and climatic conditions of the State. Since pearl millet is an important food crop that fits better in the state's physicochemical conditions of soil and agro-climatic conditions, it becomes essential to increase the average productivity of this crop in the State. The findings of the present attempt concluded that zinc sulphate @ $25 \mathrm{~kg} / \mathrm{ha}$ as soil application + foliar application of $0.5 \%$ solution of ferrous sulphate at 30 and 45 days after sowing could enhance the productivity of pearl millet in western Rajasthan conditions.

\section{ACKNOWLEDGEMENTS}

The authors are thankful to Agricultural Technology Management Agency (ATMA), Jodhpur (Rajasthan), for research funds.

\section{REFERENCES}

Ali, S.A., Khan, A., Marija, G., Arif, M., Fida, M. and Bipis, S. 2008. Assessment of different crop nutrient management practices for yield improvement. Aus. J. Crop Sci., 2(3): 150-159.

Anitha, S.E., Sreenivasan and Purushothaman, S.M. 2005. Response of cowpea to foliar nutritional of zinc and iron in the oxisols of Kerala. Legume Res., 28(4): 294-296.

Bhamare, R.S., Sawale, D.D., Jagtap, P.B., Tamboli, B.D. and Kadam, M. (2018). Effect of iron and zinc on growth and yield of French bean in iron and zinc-deficient inceptisol soil. Int. J. Chem. Stud., 6(3): 3397-3399. 
Bybordi, A. and Malakouti, M.J. 2003. Effect of iron, manganese and copper on qualitative and quantitative traits of wheat under salinity conditions. J. Soil and Water Sci., 17: 140-149.

Choudhary, H., Yadav, L.R., Yadav, M.R., Kantwa, R. and Kumawat, R. 2018. Growth and productivity of mungbean varieties under foliar application of iron in the semi-arid eastern plain zone of Rajasthan. Int. J. Chem. Stud., 6(5): 2269-2274.

Elayaraja, D. 2018. Effect of micronutrients and organic manures on sesame. J. Ecobiotechnology, 10: 12-15.

Fouda, K.F. and Abd-Elhamied, A.S. 2017. Integrated effect of foliar fertilization of $\mathrm{Fe}, \mathrm{Zn}$ and rates of $\mathrm{P}$ fertilization on growth and yield of cowpea. J. Soil Sci. and Agric. Engg., 8(12): 733-740.

Gaffar, A., Ehsanullah, Nadeem, E. and Sultan, H.K. 2011. Influence of zinc and iron on yield and quality of sugarcane planted under various trench spacing. Pak. J. Agric. Sci., 192: 181-189.

Gupta, K. 2012. Role of phosphorus and zinc in enhancing growth, yield and quality of fennel crop in the irrigated condition of North-West Rajasthan. PhD. Thesis, SKRAU, Bikaner.

Guruprasad, B.P., Kurigod, V., Hundekar, S.T. 2009. Influence of methods of iron sulphate application on yield and nutrient uptake by groundnut genotypes on calcareous soils. Karnataka J. Agric. Sci., 22(5): 1104-1106.

Habib, M. 2012. Effect of supplementary nutrition with Fe, $\mathrm{Zn}$ chelates and urea on wheat quality and quantity. Afr. J. Biotechno., 11(11): 2661-65.

Jamal, A., Khan, M.I., Tariq, M. and Fawad, M. 2018. Response of mungbean crop to different levels of applied iron and zinc. J. Horti. and Plant Res., 3: 13-22.

Karwasra, R.S. and Kumar, A. 2007. Effect of zinc application on growth, biomass and nutrient uptake by chickpea in calcareous soils. Haryana J. Agron., 23(1-2): 111-112.

Khan, Muhammad Meer, Abdul Manaf, Fayyaz-ul-Hassan and Muhammad Sheeraz Ahmed 2017. Micronutrients (Zn, B and Mn) Effects on Sesame (Sesamum indicum L.). Int. J. Agron. Agri. Res., 10(5): 92-101.

Kharol, S., Sharma, M., Purohit, H.S., Jain, H.K., Lal, M. and Sumeriya, H.K. 2014. Effect of sulphur and zinc nutrition on yield, quality and nutrient content and uptake by chickpea. Environ. and Eco., 32(4): 1470-1474.

Khorgami, A. and Farnia, A. 2006. Effect of phosphorus and zinc fertilization on yield and yield components of chickpea cultivars. Afr. Crop Sci. Conference Proce., 9: 205-208.

Kim, J. and Rees, D.C. 1992. Structural models for the metal centres in the nitrogenous molybdenum-iron protein. Sci., 257: 1677-82.

Kumawat, R.N., Rathore, P.S. and Pareek, N. 2006. Response of mungbean to $S$ and Fe nutrition grown on calcareous soil of Western Rajasthan. Ind. J. Pulses Res., 19(2): 228-230.
Malakouti, M.J. and Tehrani, M. 2005. The role of micronutrients in increasing yield and improving the quality of crops. IIIrd ed. Tarbiat Modarres University Publications.

Meena B.L., Kumar P., Kumar A., Meena R. L., Kaledhonkar M.J. and Sharma P.C. 2018. Zinc and Iron Nutrition to Increase the Productivity of Pearl Millet- Mustard Cropping System in Salt Affected Soils. Int. J. Curr.Microb. App. Sci., 7(8): 3201-3211.

Mondal, M.M.A., Rahman, M.A., Akhter, M.B. and Fakivz M.S.A. 2011. Effect of foliar application of nitrogen and micronutrient on growth and yield in mungbean. Legume Res., 34(3): 166-171.

Patel, M.M., Patel, I.C., Patel, R.I. and Acharya, S. 2011. Effect of zinc and iron on yield and yield attributes of rainfed cowpea. Annals of Arid Zone, 50(1): 17-19.

Prasad, S.K., Singh, M.K. and Singh R. 2014. Effect of nitrogen and zinc fertilizer on pearl millet (Pennisetum glauccum) under Agri-Horti system of eastern Uttar Pradesh. The Bio-scan, 9(1): 163-166.

Rakshit, A., Sarkar, B. and Abhilash, P.C. 2018. Soil Amendments for Sustainability: Challenges and Perspectives, Taylor \& Francis Group, NW, Suite 300Boca Raton, ISBN FL 978-0-8153-7077-2, Catalogue Number: K338140.

Rahman, M.M., Adan, M.J., Chowdhury, M.S.N., Ali, M.S. and Mahabub, T.S. 2015. Effect of phosphorus and zinc on growth and yield of mungbean. Int. J. Sci. and Res. Pub., 5(2): 2250-3153.

Roy, P.D., Narwal, R.P. Malik, R.S., Saha, B.N. and Kumar S. 2013. Impact of zinc application method on green gram productivity and grain zinc fortification. J. Environ. Bio., 35: 851-854.

Sahu, M.P., Kumawat, S.M., Singh, G., Ramaswamy, N.K. and Souza, S.F. 2007. Consolidated progress report of the research project "Establishment of radiotracer laboratory and multilocation testing of the crop". RAU, Bikaner.

Saini, A.K. and Singh, R. 2017. Effect of sulphur and iron fertilizer on growth and yield of green gram. Int. J. Cur. Microb. and Appl. Sci., 6(6): 1922-1929.

Salam, P.K., Rajput, R.S., Mishra, P.K., Anita. and Shrivastava, G.K. 2004. Effect of micronutrients fertilization on productivity potential of urdbean. Annals of Agric. Res., 25(2): 329-332.

Sammauria, R. and Yadav, R.S. 2010. Performance of fenugreek - pearl millet system as influenced by phosphorus and zinc application to fenugreek. Ind. J. Agrono., 55: 197-202.

Satyavathi, C.T. 2021. Annual report 2020-2021. All India Coordinated Pearl Millet Improvement Project, Indian Council of Agricultural Research, Mandor, Jodhpur 342 304, Rajasthan, India, pp. 1-18.

Sharma, K., Jain, K.K. and Sharma, S.K. 2004. Yield component of cluster bean as influenced by zinc and thiourea. $J$. Annals of Agric. Res., 25(1): 169-171.

Sharma, P. 2006. Effect of vermicompost, potassium and iron on the performance of fenugreek. Ph.D. Thesis, Rajasthan Agricultural University, Bikaner. 


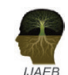

Sharma, V. and Abrol, V. 2007. Effect of phosphorous and zinc application on yield and uptake of phosphorus and zinc by chickpea under rainfed conditions. J. Food Legumes, 20: 49-51.

Singh, M.V. 2008. Micronutrient deficiencies in Indian soils and crops. In: Micronutrient deficiencies in global crop production. (Ed.B.J. Alloway). Springer Science + Business Media B.V. varieties developed at BARC. RAU, Bikaner. pp. 89-108.

Singh, V., Yadav, R.K., Yadav R., Malik, R.S., Yadav, N.R., Singh, J. and Meena, M.D. 2013. Effect of different iron and zinc applications on growth, yield and quality parameters of mungbean. Annals of Agri-Bio Res., 18(2): 164-175.

Solanki, D.R., Swata and Solanki, M.S. 2017. Growth, yield and attributes of summer green gram as influenced by the application of sulphur and zinc levels. Int. J. Agric. Sci. and Res., 7(4): 663-668.
Thalooth, A.T., Tawfik, M.M. and Mohamed, H.M. 2006. A comparative study on the effect of foliar application of zinc, potassium and magnesium on growth, yield and some chemical constituents of mungbean plants grown under water stress conditions. World J. Agric. Sci., 2(1): 37-46.

Trivedi, A.K., Hemantaranjan, A. and Pandey, S.K. 2011. Iron application may improve the growth and yield of soybean. Ind. J. Plant Physio., 16(3/4): 309-313.

Vaja, R.P., Bhuva, H.M., Mokariya, L.K. and Jani1, C.P. 2020. Effect of Zinc and Iron Fortification on Growth and Yield of Summer Pearl Millet (Pennisetum glaucum (L.) R. Br. Emend. Stuntz). Int. J. Curr. Microb. App. Sci., 9(10): 2699-2704.

Verma, H.R. and Yadav, M. 2004. Effect of sulphur and zinc on growth, metabolism, yield and quality of mungbean. National Seminar of Plant Physiology, pp. 31-32. 